\title{
Sikap, Keterampilan Individu, dan Dukungan Suami terhadap Perilaku Pencegahan Infeksi Luka Perineum Ibu Postpartum
}

\author{
Ella Yulianisa ${ }^{1}$, Maryam Syarah Mardiyah ${ }^{2}$ \\ ${ }^{1,2}$ Program Studi Kebidanan Program Sarjana Terapan Sekolah Tinggi Ilmu Kesehatan Indonesia Maju \\ Jln. Harapan Nomor 50, Lenteng Agung - Jakarta Selatan 12610 \\ Telp: (021) 78894045 Email: eyulianisa07@gmail.com; maryamsyarah@gmail.com
}

\begin{abstract}
Abstrak
Pencegahan infeksi yaitu upaya yang dilakukan individu untuk mencegah penularan infeksi dari lingkungan klien. Penelitian ini bertujuan untuk mengetahui apakah ada hubungan antara sikap, keterampilan individu, dan dukungan suami terhadap perilaku pencegahan infeksi luka perineum. Populasi penelitian ini ibu postpartum sampel 35 orang, pengambilan data dan sampel dengan kuesioner dan teknik total sampling hasil olah data menggunakan uji chi square. Hasil penelitian menunjukan dari 35 responden terdapat 23 ibu postpartum $(65,7 \%)$ yang memiliki sikap baik. dari 35 responden terdapat 27 ibu postpartum $(77,1 \%)$ dengan keterampilan individu yang terampil. dari 35 responden terdapat $30 \mathrm{ibu}$ postpartum $(85,7 \%)$ yang mendapat dukungan suami. Hasil uji statistik menunjukkan ada hubungan antara sikap, keterampilan individu, dukungan suami dengan perilaku pencegahan infeksi luka perineum pada ibu postpartum dengan sikap $\rho$ value $=0,015 \mathrm{OR}=9,333$, keterampilan individu $\mathrm{p}$ value $=0,003 \mathrm{OR}=17,250$ dan dukungan suami $\rho$ value $=0,017 \mathrm{OR}=16$. Kesimpulannya ada hubungan pencegahan infeksi luka perineum pada ibu postpartum. Disarankan untuk bidan memberikan pelatihan kepada ibu postpartum sebelum pulang seputar pencegahan infeksi luka perineum.
\end{abstract}

Kata Kunci : dukungan, keterampilan, pencegahan infeksi, sikap

\begin{abstract}
Infection prevention is an effort made by an individual to prevent transmission of infection from the client's environment. This study aims to determine whether there is a relationship between attitudes, individual skills, and husband support for perineal wound infection prevention behavior. The population in this study was postpartum mothers with 35 samples, data collection and sampling by questionnaire and total sampling technique of data processing using chi square test. The results showed that of the 35 respondents there were 23 postpartum mothers (65.7\%) who had good attitudes. of 35 respondents there were 27 postpartum mothers (77.1\%) with skilled individual skills. from 35 respondents there were 30 postpartum mothers (85.7\%) who received husband support. Statistical test results show there is a relationship between attitudes, individual skills, support of husband and behavior of prevention of perineal wound infection in postpartum mothers with attitudes $\rho$ value $=0.015 O R=9.333$, individual skills $p$ value $=0.003 O R=17.250$ and husband support $\rho$ value $=$ $0.017 O R=16$. In conclusion there is a relationship between prevention of perineal wound infection in postpartum mothers. It is recommended that midwives provide training to postpartum mothers before going home regarding the prevention of perineal wound infection.
\end{abstract}

Keywords: support, skills, prevention of infections, attitude. 


\section{Pendahuluan}

Masa nifas adalah salah satu kondisi yang perlu untuk diperhatikan dalam upaya menurunkan angka kematian ibu dan bayi di Indonesia. Dari berbagai pengalaman dalam menanggulangi kematian ibu dan bayi dibanyak negara, para pakar kesehatan menganjurkan upaya pertolongan difokuskan pada periode intrapartum. Asuhan kebidanan yang diberikan sangat mempengaruhi kualitas asuhan kebidanan yang diberikan dalam tindakan kebidanan. ${ }^{1}$

Salah satu infeksi pada masa nifas adalah infeksi yang terjadi karena perlukaan jalan lahir. Perlukaan perineum dapat terjadi karena ketidaktepatan dalam memimpin suatu persalinan namun dapat terjadi karena laserasi atau tindakan episiotomi. Episiotomi dilakukan karena memiliki beberapa manfaat yaitu mencegah terjadinya robekan perineum, mengurangi regangan otot yang terlalu kuat dan berkepanjangan pada penyangga kandung kemih atau rectum. ${ }^{2}$

Cara membersihkan luka yang tidak benar bisa berpengaruh ke kondisi perineum yang terkena lochea dan lembab akan sangat mempengaruhi berkembang biaknya bakteri dan munculnya infeksi pada luka perineum. Timbulnya infeksi pada vulva dapat merambah ke saluran uretra atau pada vagina bisa memicu terjadinya komplikasi infeksi uretra maupun infeksi pada vagina. Komplikasi yang terlambat ditangani akan berdampak pada kematian ibu nifas karena kondisi ibu postpartum yang masih lemah. Sepsis peurperalis dapat memicu masalah-masalah kesehatan menahun seperti penyakit radang panggul kronis CPD (Pelvic Inflammatory Disease) dan infertilitas. ${ }^{2}$

Menurut Laporan WHO (World Health Organization) menyebutkan bahwa sejak tahun 2000 - 2003 insiden infeksi nifas berkisar $4,5 \%-7,6 \%$ diseluruh kehamilan. Infeksi peurperalis bisa memicu kematian pada ibu di negara berkembang seperti di Afrika yang angka pertolongan persalinan oleh tenaga kesehatan kurang dari $50 \% .^{4}$

Menurut Steven, seorang tokoh WHO dalam bidang Obgyn, pada tahun 2009 diseluruh dunia terjadi 2,7 juta kasus luka robekan vagina ibu bersalin, dan $26 \%$ diantaranya terjadinya kesembuhan luka perineum yang lambat $\geq 7$ hari setelah persalinan. Angka ini diperhitungkan akan mencapai 6,3 juta pada tahun 2050. Pada tahun 2012 AKI di negara berkembang yang tertinggi adalah 450 kematian ibu per $100.000 \mathrm{KH}$ jika disamakan pada rasio kematian ibu di 9 negara maju dan 51 negara makmur. Menurut WHO $81 \%$ AKI dapat memicu komplikasi selama hamil dan bersalin 25\% selama masa postpartum. ${ }^{4}$

Pencetus kematian ibu yaitu suatu hal yang sangat berjalinan bisa di klasifikasikan pada aspek - aspek penyebab obstetri, pelayanan kesehatan, dan sosial ekonomi. Faktor komplikasi obstetric diantaranya adalah infeksi nifas pada pertolongan persalinan yang tidak mengikuti syarat-syarat asepsis antisepsis. ${ }^{5}$

Menurut laporan SDKI tahun 2012, AKI di Indonesia tercatat mencapai 359/100.00 kelahiran hidup. 5 pencetus kematian ibu yaitu pendarahan, darah tinggi dalam kehamilan (HDK), infeksi, persalinan lama dan keguguran. Kematian ibu di Indonesia masih unggul oleh 3 pencetus khusus kematian yaitu pendarahan sebesar 30,3\%,HDK sebesar $27,1 \%$, dan infeksi sebesar $7,3 \%{ }^{6}$

Diperkirakan $60 \%$ dampak kematian ibu terjadi saat kehamilan dan pasca persalinan, dan $50 \%$ kematian ibu terjadi dalam 24 jam pertama pasca persalinan. Angka kasus infeksi pada masa postpartum mendekati $2,7 \%$ dan $0,7 \%$ berkembang kearah infeksi akut. Berdasarkan hal tersebut bahwa asuhan pada masa postpartum sangat diperlukan pada saat ini karena merupakan masa darurat baik ibu maupun bayi. ${ }^{6}$

Lima Pencetus kematian ibu tertinggi yaitu perdarahan $(30,1 \%)$, hypertensi $(27,1 \%)$, infeksi $(7,3 \%)$,dan partus lama atau macet $(1,8 \%)$, dan abortus (1,6\%). Kejadian kematian ibu di Indonesia karena partus lama dalam waktu 2010-2013 mengalami fluktuatif yaitu $1,0 \%$ ditahun 2010 , meningkat menjadi $1,1 \%$ pada tahun 2011 kembali naik ditahun 2012 menjadi $1,8 \%$, kembali turunpada tahun 2013 yaitu menjadi $0 \%{ }^{7}$

Beberapa faktor penyebab terbanyak terjadinya infeksi postpartum antara lain, persalinan lama khususnya dengan pecah ketuban, bermacam - macam pemeriksaan 
vagina selama persalinan, tehnik aseptic tidak sempurna, tidak memperhatikan tehnik mencuci tangan dan manipilasi intrauteri (misalnya eksplorasi uteri, plasenta manual). ${ }^{8}$

Sikap yaitu respon yang masih tertutup dari seorang terhadap stimulasi atau objek. Sikap secara nyata memperlihatkan implikasi adanya keserasian reaksi terhadap stimulasi tertentu didalam kehidupan merupakan respon yang berupa timbulnya perasaan terhadap stimulasi social. Newcomb seorang ahli jiwa sosial yang mengatakan sikap adalah kesiapan atau kesediaan untuk bertindak, dan bukan merupakan pelaksanaan motif tertentu. ${ }^{9}$

Pada masa nifas asuhan kebidanan lebih ditujukan kepada upaya pencegahan (Preventif) terhadap infeksi, karena pada akhir hari kedua nifas kuman - kuman di vagina dapat mengadakan kontaminasi, tetapi tidak semua wanita mengalami infeksi oleh karena adanya lapisan pertahanan leukosit dan kuman - kuman relatif tidan virulen serta penderita mempunyai kekebalan terhadap infeksi. ${ }^{10}$

Pada masa postpartum, seorang ibu sangat rentan terhadap infeksi. Oleh karena itu kebersihan diri sangat penting untuk mencegah terjadinya infeksi. Kebersihan body, pakaian, tempat tidur, dan lingkungan sangat penting untuk tetap dijaga. Saat ibu mandi bersihkan seluruh tubuh sampai ke perineum dengan memakai sabun ${ }^{10}$.

Dukungan suami adalah dukungan, dorongan, perhatian dan bantuan yang diberikan oleh pasangan hidup dalam hal ini suami dalam setiap upaya untuk kebaikan keluarga. Hal ini sesuai dengan pernyataan Green dalam Notoadmodjo (2010) tentang faktor reinforcing (penguat) yaitu faktor yang mendorong atau memperkuat seseorang melakukan tindakan diantaranya dukungan suami, dukungan keluarga dan dukungan petugas. ${ }^{11}$

Dampak jika ibu tidak melakukan Pencegahan Infeksi pada Luka Perineum ibu maka akan timbul beragam masalah seperti pengeluaran cairan vagina/flour albous, iritasi didaerah vulva, timbulnya masalah infeksi pada saluran kemih, bau yang tidak menyenangkan dan infeksi pada daerah vagina (vaginitis), Serta berbagai macam infeksi lainnya. ${ }^{12}$
Melihat data sementara dari hasil penelitian sebelumnya maka dari itu peneliti tertarik untuk melakukan penelitian terkait dengan judul "Hubungan sikap, keterampilan individu, dan dukungan suami terhadap perilaku pencegahan infeksi luka perineum di BPM “E” di Limo Depok tahun 2018.

\section{Metode}

Penelitian ini menggunakan desain penelitian kuantitatif dan cross sectional. Dimana variabel bebas dan variabel terikat dalam penelitian ini dikumpulkan secara bersamaan. dimana variabel independen dalam penelitian ini adalah sikap, keterampilan individu, dukungan suami dan variabel dependennya perilaku pencegahan infeksi luka perineum pada ibu postpartum. Instrument atau alat ukur dalam penelitian dengan alat bantu kuesioner.

Penelitian ini dilakukan di Bidan Praktek Mandiri "E" di Limo Depok Tahun 2018. Pelaksanaan kegiatan penelitian dimulai dari perencanaan, persiapan, penyebaran kuesioner, pengolahan data, analisis data serta penyajian data. Penelitian ini ingin mengkaji hubungan sikap, keterampilan individu, dukungan suami terhadap perilaku pencegahan infeksi luka perineum pada ibu postpartum.

Populasi adalah keseluruhan objek penelitian atau objek yang diteliti. ${ }^{14}$ Populasi atau yang sering dikenal dengan universe adalah keseluruhan atau totalitas dari objek yang diteliti atau populasi itu adalah kumpulan objek penelitian dimana data akan dijaring serta dikumpulkan. Populasi penelitian ini yaitu seluruh ibu postpartum 6 hari di BPM "E" di Limo Depok pada bulan Februari 2018 yang berjumlah 35 responden.

Sampel adalah sebagian dari populasi ya ng nilai / karakteristik nya kita ukur dan yang nantinya kita pakai untuk menduga karakteristik dari populasi. ${ }^{15}$ Sampel adalah bagian dari populasi dimana cara pengambilannya menggunakan cara tertentu, dimana pengukuran itu dilakukan. Sampel dalam penelitian ini yaitu ibu postpartum 6 hari. Sampel pada penelitian ini ditentukan dengan teknik total sampling adalah teknik penentuan sampel dengan mengambil seluruh anggota populasi sebagai responden atau sampel.Kriteria non inklusi adalah karakteristik yang tidak termasuk kedalam 
penelitian yaitu ibu yang tidak sedang postpartum, ibu yang tidak bersedia menjadi responden dan ibu yang tidak hadir saat menjadi responden.

Kriteria eksklusi dalam penelitian ini tidak ada, karena semua target sampel memenu hi kriteria inklusi dan semua data primer terisi lengkap oleh responden melalui kuesioner. Data yang digunakan adalah data primer, yaitu sumber - sumber dasar yang terdiri dari bukti bukti atau saksi utama dari kejadian objek yang diteliti dan gejala yang terjadi dilapangan.

Data primer diperoleh secara langsung dari sumbernya dan diperoleh dari jawaban atas pertanyaan yang disediakan melalui pengisian kuesioner oleh ibu nifas yang ada di Bidan "E" maupun yang melakukan kunjungan ulang, selain data primer juga terdapat data sekunder yaitu data diperoleh dari catatan dokumen yang dimiliki oleh Bidan praktek mandiri "E" di Limo Depok.

Uji instrument penelitian dilakukan dengan menggunakan uji validitas dan uji reabilitas. Hasil pengukuran variabel perilaku pencegahan infeksi luka perineum dari 9 pernyataan dalam kuesioner, didapatkan semua pernyataan kuesioner memenuhi syarat atau valid dan reliable yaitu nilai $r_{\text {hitung }}>r_{\text {tabel }}$ selain itu semua daftar pertanyaan pada variabel sikap valid dan reliable, serta semua daftar pertanyaan keterampilan individu dan dukungan suami valid dan reliable.

Langkah pengumpulan data penelitian ini dilakukan dengan cara, Membuat surat permohonan izin pengambilan data dan izin penelitian pada Bidan Praktek Mandiri "E" di Limo Depok yang dikeluarkan oleh BAAK STIKIM, Mengajukan izin penelitian kepada Bidan Praktek Mandiri "E" di Limo Depok untuk mengadakan penelitian, Mengadakan pengkajian data yang relevan yang dapat mendukung penelitian di Bidan Praktek Mandiri "E" di Limo Depok,

Memberikan penjelasan singkat tentang rencana kegiatan penelitian dan tujuan penelitian kepada responden yang setuju berpartisipasi dalam penelitian ini, Responden diberi kuesioner untuk diisi sesuai dengan petunjuk yang telah diberikan dalam format pertanyaan kuesioner.
Responden diarahkan untuk mengisi semua pertanyaan yang telah disiapkan sesuai dengan kejadian yang benar terjadi kepada responden sehingga mengurangi terjadinya bias antara hasil penelitian dengan kejadian dilapangan, Apabila ada pertanyaan yang kurang dimengerti dapat ditanyakan kepada peneliti dan Langkah terakhir setelah kuesioner dikumpulkan, dilakukan pengolahan data dan analisis data menggunakan analisis uji chi square.

\section{Hasil}

Tabel 1. Distribusi frekuensi berdasarkan sikap, keterampilan individu, dukungan suami dan perilaku pencegahan infeksi luka perineum di Bidan Praktek Mandiri "E" di Limo Depok Tahun 2018

\begin{tabular}{clcc}
\hline No. & \multicolumn{1}{c}{ Variabel } & N & \% \\
\hline 1 & Sikap & 12 & 34,3 \\
& Tidak Baik & 23 & 65,7 \\
& Baik & & \\
2 & Keterampilan individu & 8 & 22,9 \\
& Tidak Terampil & 27 & 77,1 \\
& Terampil & & \\
3 & DukunganSuami & 5 & 14,3 \\
& Tidak Mendukung & 30 & 85,7 \\
& Mendukung & & \\
4 & Perilaku pencegahan infeksi & & \\
& luka perineum & 10 & 28,6 \\
& Tidak Baik & 25 & 71,4 \\
& Baik & & \\
\hline
\end{tabular}

Sumber: hasil olah data tahun 2018

Berdasarkan tabel di atas, menunjukkan bahwa sebagian besar responden ibu postpartum di BPM "E" Limo Depok dari 35 responden yang bersikap baik, yaitu sebanyak 23 responden $(65,7 \%)$ dan sebanyak 12 responden $(34,3 \%)$ yang bersikap tidak baik. yang memiliki keterampilan individu terampil yaitu sebanyak 27 responden $(77,1 \%)$ dan sebanyak 8 responden $(22,9 \%)$ dengan keterampilan individu tidak terampil. yang mempunyai dukungan suami yang mendukung yaitu sebanyak 30 responden $(85,7 \%)$ dan sebanyak 5 responden (14,3\%) yang tidak mendapat dukungan dari suami. dan sebagian besar responden yang berperilaku pencegahan infeksi luka perineum yang baik yaitu 25 responden $(71,4 \%)$ dan sebanyak $10(28,6 \%)$ 
Tabel 2. Hubungan sikap, keterampilan individu, dukungan suami dan perilaku pencegahan infeksi luka perineum di Bidan Praktek Mandiri “E” di Limo Depok Tahun 2018.

\begin{tabular}{|c|c|c|c|c|c|c|c|c|}
\hline \multirow{3}{*}{ Variabel } & \multicolumn{4}{|c|}{$\begin{array}{c}\text { Perilaku pencegahan infeksi } \\
\text { luka perineum }\end{array}$} & \multirow{2}{*}{\multicolumn{2}{|c|}{ Total }} & \multirow{3}{*}{$\begin{array}{c}\rho \\
\text { value }\end{array}$} & \multirow{3}{*}{ OR } \\
\hline & \multicolumn{2}{|c|}{ Tidak Baik } & \multicolumn{2}{|c|}{ Baik } & & & & \\
\hline & $\mathbf{F}$ & $\%$ & $\mathbf{F}$ & $\%$ & $\mathbf{F}$ & $\%$ & & \\
\hline \multicolumn{9}{|l|}{ Sikap } \\
\hline Tidak Baik & 7 & 58,3 & 5 & 41,7 & 12 & 100 & \multirow[t]{2}{*}{0,015} & \multirow[t]{2}{*}{9,333} \\
\hline Baik & 3 & 13,0 & 20 & 87,0 & 23 & 100 & & \\
\hline \multicolumn{9}{|l|}{ KeterampilanIndividu } \\
\hline TidakTerampil & 3 & 75,0 & 1 & 25,0 & 4 & 100 & \multirow{2}{*}{0,003} & \multirow{2}{*}{17,250} \\
\hline Terampil & 7 & 22,6 & 24 & 77,4 & 31 & 100 & & \\
\hline \multicolumn{9}{|l|}{ Dukungan Suami } \\
\hline Tidak Mendukung & 4 & 80,0 & 1 & 20,0 & 5 & 100 & \multirow[t]{2}{*}{0,017} & \multirow[t]{2}{*}{16,000} \\
\hline Mendukung & 6 & 20,0 & 24 & 80,0 & 30 & 100 & & \\
\hline
\end{tabular}

yang memiliki perilaku pencegahan infeksi luka perineum yang tidak baik.

Analisa univariat adalah langkah mengeksplorasi data dari suatu variabel, biasanya dilakukan untuk meringkas data menjadi ukuran tertentu. yaitu sikap, keterampilan individu dukungan suami dan perilaku pencegahan infeksi luka perineum dalam bentuk distribusi frekuensi. Sedangkan analisa bivariat adalah untuk melihat hubungan antara variabel maka analisis bivariat dilakukan untuk melihat hubungan antara sikap, keterampilan individu dan dukungan suami terhadap perilaku pencegahan infeksi luka perineum pada ibu postpartum.

Berdasarkan tabel diatas, menunjukan bahwa dari 12 responden yang memiliki sikap tidak baik terdapat 7 ibu (58,3\%) yang memiliki perilaku pencegahan infeksi luka perineum yang tidak baik. Sedangkan dari 23 responden yang memiliki sikap baik terdapat 20 ibu (87,0\%) yang memiliki perilaku pencegahan infeksi luka perineum yang baik. Hasil uji statistic chi square hubungan sikap dengan perilaku pencegahan infeksi luka perineum pada ibu postpartum diperoleh nilai $\rho$ value $=0,015(\rho<0,05)$ sehingga dapat disimpulkan hipotesisi nol (Ho) ditolak sehingga ada hubungan antara sikap ibu dengan perilaku pencegahan infeksi luka perineum pada ibu postpartum. Dan didapat $\mathrm{OR}=9,333$ yang artinya responden yang memiliki sikap baik berpeluang 9,3 kali untuk berperilaku baik dalam pencegahan infeksi luka perineum dibandingkan dengan ibu yang memiliki sikap tidak baik. bahwa dari 4 responden yang memiliki keterampilan individu tidak terampil terdapat 3 ibu $(75,0 \%)$ yang berperilaku pencegahan infeksi luka perineum tidak baik. Sedangkan dari 31 reponden yang memiliki keterampilan individu terampil terdapat 24 ibu $(77,4 \%)$ yang berperilaku pencegahan infeksi luka perineum baik. Hasil uji statistic chi square hubungan keterampilan individu dengan perilaku pencegahan infeksi luka perineum pada ibu postpartum diperoleh nilai $\rho$ value $=0,003(\rho<$ 0,05 ) sehingga dapat disimpulkan hipotesisi nol (Ho) ditolak sehingga dapat disimpulkan ada hubungan antara keterampilan individu dengan perilaku pencegahan infeksi luka perineum pada ibu postpartum. Dan didapat $\mathrm{OR}=17,250$ yang artinya responden yang memiliki keterampilan individu yang terampil berpeluang 17,2 kali untuk berperilaku baik dalam pencegahan infeksi luka perineum dibandingkan dengan ibu yang tidak terampil.

Berdasarkan tabel diatas,menunjukan bahwa dari 5 responden yang memiliki dukungan suami yang tidak mendukung terdapat 4 ibu $(80,0 \%)$ yang berperilaku pencegahan infeksi luka perineum tidak baik. Sedangkan dari 30 responden yang memiliki dukungan suami yang mendukung terdapat 24 ibu $(80,0 \%)$ yang berperilaku pencegahan infeksi luka perineum baik. Hasil uji statistic chi square hubungan dukungan suami dengan perilaku pencegahan infeksi luka perineum pada ibu postpartum diperoleh nilai $\rho$ value $=$ $0,017(\rho<0,05)$ sehingga dapat disimpulkan hipotesis nol (Ho) ditolak sehingga ada hubungan antara dukungan suami dengan perilaku pencegahan infeksi luka perineum 
pada ibu postpartum. Dan didapat $\mathrm{OR}=16$ yang artinya responden yang mendapat dukungan suami berpeluang 16 kali untuk memiliki perilaku pencegahan infeksi luka perineum yang baik dibandingkan dengan ibu postpartum yang tidak mendapat dukungan suami.

\section{Pembahasan}

\section{Perilaku Pencegahan Infeksi Luka Perineum}

Berdasarkan hasil penelitian tabel perilaku pencegahan infeksi luka perineum menunjukan bahwa dari 35 responden terdapat 25 ibu postpartum $(71,4 \%)$ dengan perilaku pencegahan infeksi yang baik dan terdapat 10 ibu postpartum $(28,6 \%)$ dengan perilaku pencegahan infeksi luka perineum tidak baik.

Perawatan luka perineum yaitu kebutuhan untuk membersihkan dan menyehatkan daerah antara paha dengan pembatas vulva dan anus pada ibu dalam masa antara kelahiran plasenta sampai dengan kembalinya organ seperti sebelum hamil. ${ }^{16}$

Perawatan perineum menurut Hamilton untuk mencegah terjadinya infeksi yang berhubungan dengan kesembuhan organ. Lingkup perawatan perineum adalah mencegah kontaminasi dari rectum, menangani dengan lembut pada jaringan yang terkena trauma, bersihkan semua keluaran yang menjadi sumber bakteri dan bau. ${ }^{17}$

Peneliti berpendapat bahwa ibu postpartum di BPM "E" di Limo Depok sebagian besar berperilaku pencegahan infeksi luka perineum yang baik.

\section{Sikap dengan Perilaku Pencegahan Infeksi Luka Perineum}

Berdasarkan tabel distribusi frekuensi si kap ibu menunjukan bahwa dari 35 responden terdapat 23 ibu postpartum $(65,7 \%)$ yang mem iliki sikap baik dan terdapat $12 \mathrm{ibu}$ postpartum (34,3\%) yang memiliki sikap tidak baik.

Sikap ialah kesediaan atau kesigapan untuk bertingkah laku dan bukan merupakan pelaksana motif tertentu. Selain itu sikap dapat ditafsirkan sebagai kecenderungan bertindak, berfikir, berpersepsi dan memiliki rasa dalam menghadapi objek, ide, situasi, atau nilai. Sikap tidak sama dengan perilaku, tetapi merupakan kecenderungan untuk berperilaku dengan cara tertentu terhadap objek sikap. Sikap relatif lebih konsisten atau jarang mengalami perubahan. ${ }^{9}$

Peneliti berpendapat bahwa ibu postpartum di BPM "E" di Limo Depok memiliki sikap yang baik terhadap perilaku pencegahan infeksi luka perineum.

\section{Keterampilan Individu dengan perilaku pencegahan infeksi luka perineum}

Berdasarkan hasil penelitian menunjukan bahwa dari 35 responden terdapat 27 ibu postpartum $(77,1 \%)$ dengan keterampilan individu yang terampil dan terdapat 8 ibu postpartum $(22,9 \%)$ dengan keterampilan individu tidak terampil.

Keterampilan merupakan kepiawaian untuk melakukan pekerjaan secara mudah dan tepat. Sedangkan vulva hygiene ialah suatu langkah untuk merawat organ kewanitaan bagian luar yang dilakukan dalam upaya menjaga kesehatan dan mencegah infeksi. Karena keterampilan vulva hygiene sangat penting untuk melakukan pencegahan infeksi luka perineum pada ibu nifas sehingga tidak akan timbul masalah infeksi nifas. Jadi disini penulis memperjelas bahwa variabel keterampilan individu yaitu Keterampilan Vulva Hygiene. ${ }^{18}$

Peneliti berpendapat bahwa ibu postpartum di BPM "E" di Limo Depok sebagian besar terampil dalam melakukan pencegahan infeksi luka perineumnya sehingga pencegahan infeksi dapat diatasi dengan baik.

\section{Dukungan Suami dengan Perilaku Pencegahan Infeksi Luka Perineum}

Berdasarkan hasil penelitian dukungan suami menunjukan bahwa dari 35 responden terdapat $30 \mathrm{ibu}$ postpartum $(85,7 \%)$ yang mendapat dukungan dari suami dan terdapat 5 ibu postpartum $(14,3 \%)$ yang tidak mendapat dukungan dari suami.

Dukungan suami merupakan suatu bentuk dorongan, perhatian dan bantuan yang diberikan oleh pasangan hidup dalam setiap upaya untuk kebaikan dan kesejahteraan keluarga. Keberadaan dukungan suami sangat penting bagi seorang istri dalam setiap pengambilan keputusan dan perilaku kesehatan, seorang suami merupakan kepala rumah tangga dan memiliki peran dalam 
menentukan keputusan penting dalam kehidupan rumah tangga. Dukungan suami dapat memiliki dampak yang sangat besar bagi istri ketika istri harus menentukan tindakan yang terbaik yang harus dipilih. ${ }^{19}$

Peneliti berpendapat bahwa ibu postpartum di BPM "E" Limo Depok sebagian besar mendapatkan dukungan dari suami terhadap pencegahan infeksi luka perineum.

\section{Hubungan Antara Sikap dengan Perilaku Pencegahan Infeksi Luka Perineum}

Hasil uji statistic chi square hubungan sikap dengan perilaku pencegahan infeksi luka perineum pada ibu postpartum diperoleh nilai $\rho$ value $=0,015(\rho<0,05)$ sehingga dapat disimpulkan hipotesisi nol (Ho) ditolak sehingga ada hubungan antara sikap dengan perilaku pencegahan infeksi luka perineum pada ibu postpartum. Dan didapat OR $=9,333$ yang artinya sikap ibu yang baik berpeluang 9,3 kali untuk pencegahan infeksi luka perineum dibandingkan responden yang bersikap tidak baik.

Hasil penelitian lain juga memperlihatkan hasil yang kurang lebih sama. Menurut Hasil penelitian Lia Dahliawati (2014) dengan judul hubungan sikap dan pengetahuan ibu terhadap perilaku pijatan perineum untuk mencegah rupture perineum di wilayah kerja Puskesmas Kali Bunder Kabupaten Sukabumi tahun 2014 didapatkan hasil analisa hubungan sikap terhadap perilaku pijatan perineum bahwa sebanyak 26 (78\%) sikap buruk dengan perilaku buruk dan 7 responden $(21,2 \%)$ sikap buruk dengan perilaku baik sedangkan sikap baik dengan perilaku buruk 11 responden $(39,3 \%)$ dan 17 responden $(60,7 \%)$ sikap baik dengan perilaku baik. Hasil uji statistic didapat nilai $\mathrm{P}=0,004$ berarti $\mathrm{P}>0,05$ sehingga dapat disimpulkan bahwa ada hubungan yang signifikan antara sikap terhadap perilaku pijatan perineum. Dari nilai OR 5,740 (1,859-17,729) dapat disimpulkan bahwa responden yang sikap buruk berpeluang 5,7 kali mengalami perilaku buruk dibandingkan sikap baik. ${ }^{20}$

Sikap ialah kesediaan atau kesigapan untuk bertingkah laku dan bukan merupakan pelaksana motif tertentu. Selain itu sikap dapat ditafsirkan sebagai kecenderungan bertindak, berfikir, berpersepsi dan memiliki rasa dalam menghadapi objek, ide, situasi, atau nilai.
Sikap tidak sama dengan perilaku, tetapi merupakan kecenderungan untuk berperilaku dengan cara tertentu terhadap objek sikap. Sikap relatif lebih konsisten atau jarang mengalami perubahan. ${ }^{9}$

Menurut pendapat peneliti terdapat hubungan antara sikap dengan perilaku pencegahan infeksi luka perineum pada ibu postpartum karena sikap ibu yang baik akan mempengaruhi pencegahan infeksi luka perineum.

\section{Hubungan Antara Keterampilan Individu dengan Perilaku Pencegahan Infeksi Luka Perineum}

Hasil uji statistic chi square hubungan keterampilan individu dengan perilaku pencegahan infeksi luka perineum pada ibu postpartum diperoleh nilai $\rho$ value $=0,003(\rho<$ $0,05)$ sehingga dapat disimpulkan hipotesisi nol (Ho) ditolak sehingga dapat disimpulkan ada hubungan antara keterampilan individu dengan perilaku pencegahan infeksi luka perineum pada ibu postpartum. Dan didapat $\mathrm{OR}=17,250$ yang artinya responden yang memiliki keterampilan individu yang terampil berpeluang 17,2 kali untuk berperilaku baik dalam pencegahan infeksi luka perineum dibandingkan dengan ibu yang tidak terampil.

Berdasarkan hasil penelitian yang dilakukan oleh Sriani Timbawa (2015) dengan menggunakan analisa statistik uji chi square pada tingkat signifkansi $\alpha=0,0$. Didapatkan hasil uji statistik diperoleh nilai $\mathrm{p}=0,001<\alpha$ $(0,05)$ dengan demikian dapat dikatakan bahwa ada hubungan vulva hygiene dengan pencegahan infeksi luka perineum pada ibu postpartum di Rumah Sakit Pancaran Kasih GMIM Manado. Kemudian didapatkan OR = 10,667 yang berarti bahwa peran vulva hygiene baik berpeluang 10 kali lebih besar terhadap pencegahan infeksi dibandingkan dengan vulva hygiene kurang. Kesimpulan terdapat hubungan antara keterampilan individu dengan perilaku pencegahan infeksi luka perineum pada ibu postpartum. ${ }^{21}$

Keterampilan merupakan kepiawaian untuk melakukan pekerjaan secara mudah dan tepat. Sedangkan vulva hygiene ialah suatu langkah untuk merawat organ kewanitaan bagian luar yang dilakukan dalam upaya menjaga kesehatan dan mencegah infeksi. Karena keterampilan vulva hygiene sangat 
penting untuk melakukan pencegahan infeksi luka perineum pada ibu nifas sehingga tidak akan timbul masalah infeksi nifas. ${ }^{18}$

Menurut pendapat peneliti keterampilan ibu dalam membersihkan luka perineum itu sangatlah penting untuk mencegah terjadinya infeksi pada luka perineum ibu, didalam penelitian yang saya lakukan tidak adanya hubungan antara keterampilan ibu (vulva hygiene) dengan perilaku pencegahan infeksi luka perineum karena kurangnya keterampilan ibu dalam membersihkan luka perineumnya karena mereka berpendapat karena takut membersihkan karena ada jahitannya, sehingga pencegahan infeksi luka perineum tidak bisa diatasi.

\section{Hubungan Antara Dukungan Suami dengan Perilaku Pencegahan Infeksi Luka Perineum}

Hasil uji statistic chi square hubungan dukungan suami dengan perilaku pencegahan infeksi luka perineum pada ibu postpartum diperoleh nilai $\rho$ value $=0,017(\rho<0,05)$ sehingga dapat disimpulkan hipotesis nol (Ho) ditolak sehingga ada hubungan antara dukungan suami dengan perilaku pencegahan infeksi luka perineum pada ibu postpartum. Dan didapat OR $=16$ yang artinya dukungan suami yang mendukung berpeluang 16 kali untuk pencegahan infeksi luka perineum dibandingkan dukungan suami yang tidak mendukung.

Menurut hasil penelitian Syamsiyatul Musyriqoh (2016) dengan menggunakan analisis uji Chi Square didapatkan hasil penelitian menunjukkan hubungan dukungan suami dengan perilaku pecegahan terhadap kanker serviks adalah dukungan suami baik dengan perilaku pencegahan terhadap kanker serviks baik sebesar 31 responden $(21,83 \%)$ dan dukungan suami baik dengan perilaku pencegahan terhadap kanker serviks buruk 29 responden (20,43\%). Berdasarkan hasil tersebut bahwa secara statistic terdapat hubungan dukungan suami dengan perilaku pencegahan kanker serviks. Tingkat kepercayaan yang digunakan adalah 95\% dengan ( $\mathrm{p}$ value $=0,003$ dan $\alpha=0,05) .{ }^{20}$

Dukungan suami merupakan suatu bentuk dorongan, perhatian dan bantuan yang diberikan oleh pasangan hidup dalam setiap upaya untuk kebaikan dan kesejahteraan keluarga. Keberadaan dukungan suami sangat penting bagi seorang istri dalam setiap pengambilan keputusan dan perilaku kesehatan, seorang suami merupakan kepala rumah tangga dan memiliki peran dalam menentukan keputusan penting dalam kehidupan rumah tangga. Dukungan suami dapat memiliki dampak yang sangat besar bagi istri ketika istri harus menentukan tindakan yang terbaik yang harus dipilih. ${ }^{19}$

Menurut pendapat peneliti terdapat hubungan antara dukungan suami dengan perilaku pencegahan infeksi luka perineum pada ibu postpartum karena dukungan suami sangat berpengaruh dalam melakukan suatu tindakan pencegahan infeksi, karena dukungan suami yang baik akan mempengaruhi pencegahan infeksi luka perineum ibu.

\section{Kesimpulan}

Berdasarkan hasil penelitian yang dilakukan penulis tentang hubungan sikap, keterampilan individu, dan dukungan suami terhadap perilaku pencegahan infeksi luka perineum pada ibu postpartum di BPM "E" Di limo depok tahun 2018. Sesuai dengan hasil penelitian yang dilakukan dapat ditarik kesimpulan sebagai berikut yaitu Ada hubungan antara sikap dengan perilaku pencegahan infeksi luka perineum pada ibu postpartumdengan nilai $\rho$ value $=0,015$ dan nilai $\mathrm{OR}=9,333$. Ada hubungan antara keterampilan individu (vulva hygiene) dengan pencegahan infeksi luka perineum pada ibu postpartum dengan nilai $\mathrm{p}$ value $=0,003$ dan nilai $\mathrm{OR}=17,250$. Ada hubungan antara dukungan suami dengan pencegahan infeksi luka perineum pada ibu postpartum dengan nilai $\rho$ value $=0,017$ dan nilai $\mathrm{OR}=16$.

\section{Saran}

Saran kepada bidan untuk memberikan pelatihan kepada ibu postpartum sebelum pulang seputar pencegahan infeksi luka perineum. Diharapkan kepada BPM "E" untuk mendorong bidan pelaksana untuk mengikuti pelatihan dan seminar yang terupdate. Diharapkan penelitian ini dapat dijadikan sebagai penambah wawasan dan untuk menerapkan ilmu yang telah didapatkan pada perkuliahan kepada masyarakat serta dapat melanjutkan penelitian ini dengan mengguna- 
kan metode penelitian yang lain misalnya dengan penelitian eksperimen.

\section{Daftar Pustaka}

1. Yulia Widianti. Pengetahuan dan Sikap ibu nifas terhadap pelaksanaan kunjungan masa nifas pada pasien di rumah bersalin delima medan tahun 2013. USU-IR; 2013.

2. Nuraisyah Nasution. Faktor-faktor yang berhubungan dengan terjadinya rupture perineum pada ibu bersalin di rsu dr. pirngadi medan periode januari - desember 2007. USU-IR; 2011.

3. Angka kejadian AKI menurut WHO.(http://ke sehatan.ibu.depkes.go.id/);2013 diakses pada tanggal 20 januari 2018 pukul 16.00 wib

4. Saifudin A. Buku acuan nasional, pelayanan kesehatan.maternal dan neonatal. Jakarta : Yayasan Bina Pustaka-Sarwono Prawirohardjo; 2001.

5. Roidatus Salma Hanifah. Faktor-faktor yang berhubungan dengan kejadian depresi postpartum di wilayah kerja puskesmas karanganyar kabupaten karanganyar tahun 2017. UMS; 2017.

6. Kemenkes RI. Profil kesehatan indonesia tahun 2015. Jakarta; 2015.

7. Sunarsih T.Asuhan kebidanan pada ibu nifas.Jakarta : Salemba Medika; 2011.

8. Tri Nurwibowo. Peningkatan sikap demokratis siswa kelas VIII a smp negeri 06 kroya dengan penerapan metode think talk write pada kompetensi dasar pelaksanaan demokrasi dalam berbagai aspek kehidupan dalam pembelajaran pendidikan kewarganegaraan. UMP; 2017.

9. Nurdahliana. Faktor yang memengaruhi penyembuhan luka perineum pada ibu pasca persalinan normal di wilayah kerja puskesmas jeumpa, gandapura, dan kuta blang kabupaten bireuen. USU-IR; 2015.
10. Notoadmodjo S. Promosi kesehatan danperila ku kesehatan.Jakarta:Rineka Cipta; 2010.

11. Ayu Hk.Aplikasi praktis asuhan keperawatan keluarga. Jakarta : Sagung Seto;2010.

12. Evi Risnawati. Survey angka kejadian BPM. Depok; 2017.

13. Notoadmodjo S.Metodologi penelitian kesehat an. Jakarta : Rineka Cipta; 2012.

14. Sutanto P.Statistik kesehatan, Cetakan Keenam, Jakarta: PT Rajagrafindo Pustaka; 2011.

15. Verby Divini Prety, Rina Kundre, Yolanda Bataha. Hubungan perawatan luka perineum dengan perilaku personal hygiene ibu post partum di rumah sakit pancaran kasih gmim manado. E-Journal Keperawatan (e-Kp) Volume 5 Nomor 1 Februari 2017; 2017.

16. Rukiyah Ai Yeyeh. Dkk.Asuhan Kebidanan III (masa nifas). Jakarta : Trans info media; 2011.

17. Ayu Hk. Aplikasi praktis asuhan keperawatan keluarga. Jakarta : Sagung Seto;2010

18. Sudiharto.Asuhan Keperawatan keluarga dengan pendekatan keperawatan transkultural ; editor, Esty Whayuningsih. Jakarta : EGC; 2007.

19. Dahliawati L. Hubungan sikap dan pengetahuan ibu terhadap perilaku pijatan perineum untuk mencegah ruptur perineum diwilayah kerja Puskesmas Kali Bunder Kabupaten Sukabumi Tahun 2014. Sukabumi;Stikim; 2014.

20. Timbawa S. Hubungan vulva hygiene dengan pencegahan infeksiluka perineum pada ibu postpartum di rumah sakit pancaran kasih gmim manado tahun 2015. Manado;Universitas Sam Ratulangi ; 2015.

21. Musyriqoh S.Hubungan dukungan suami dengan perilaku pencegahan terhadap kanker serviks pada wanita dewasa awal didesa balung lor kecamatan balung kabupaten jember tahun 2016. Jember;Universitas Jember ; 2016. 